\title{
General-television programming in Europe (UE5): Public versus commercial channels
}

\author{
Emili Prado; Matilde Delgado; Núria García-Muñoz; Belén Monclús; Celina Navarro
}

Nota: Este artículo se puede leer en español en:

http://www.elprofesionaldelainformacion.com/contenidos/2020/mar/prado-delgado-garcia-monclus-navarro_es.pdf

How to cite this article:

Prado, Emili; Delgado, Matilde; García-Muñoz, Núria; Monclús, Belén; Navarro, Celina (2020). "General-television programming in Europe (UE5): Public versus commercial channels". El profesional de la información, v. 29, n. 2, e290204.

https://doi.org/10.3145/epi.2020.mar.04

Manuscript received on $15^{\text {th }}$ July 2019 Accepted on $29^{\text {th }}$ January 2020

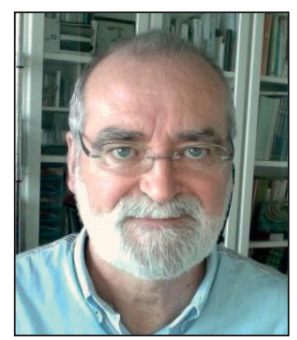

Emili Prado

https://orcid.org/0000-0003-4871-2472

Universitat Autònoma de Barcelona Dep. de Com. Audiovisual i Publicitat. Edifici I. Campus de la UAB. 08193 Bellaterra (Barcelona), Spain emili.prado@uab.cat

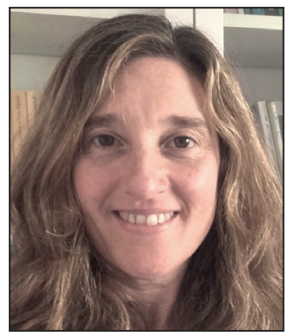
Matilde Delgado https://orcid.org/0000-0002-3071-5934

Universitat Autònoma de Barcelona Dep. de Com. Audiovisual i Publicitat. Edifici l. Campus de la $U A B$. 08193 Bellaterra (Barcelona), Spain matilde.delgado@uab.cat

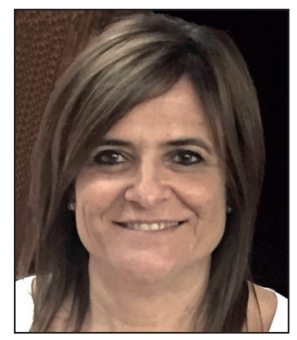

\section{Núria García-Muñoz}

https://orcid.org/0000-0002-6169-8428

Universitat Autònoma de Barcelona Dep. de Com. Audiovisual i Publicitat. Edifici I. Campus de la UAB. 08193 Bellaterra (Barcelona), Spain nuria.garcia@uab.cat

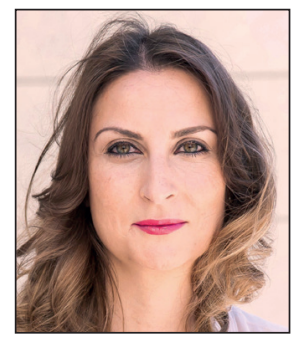

\section{Belén Monclús}

https://orcid.org/0000-0002-8026-6778

Universitat Autònoma de Barcelona Dep. de Com. Audiovisual i Publicitat. Edifici I. Campus de la UAB. 08193 Bellaterra (Barcelona), Spain belen.monclus@uab.cat

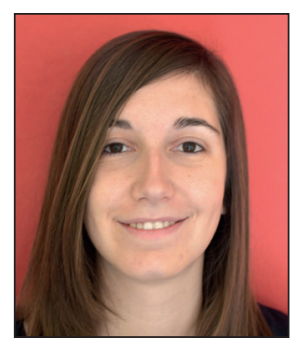

\section{Celina Navarro \\ https://orcid.org/0000-0002-3127-7358}

Universitat Autònoma de Barcelona Dep. de Com. Audiovisual i Publicitat. Edifici I. Campus de la UAB. 08193 Bellaterra (Barcelona), Spain celina.navarro@uab.cat

\begin{abstract}
Technological convergence has affected the media context of generalist television, modifying access and the consumption of content. The design of the scheduling of the general-interest linear television is a key element in understanding the policies that the operators follow when offering genres and formats, and in observing the similarities and differences between public and private ownership. This article analyses the television schedules of 25 generalist channels, public and commercial, operating in Germany, Spain, France, Italy and the United Kingdom. Some of the findings of this investigation show a) little diversity of genres, b) that the editorial policy of public broadcasters clearly differentiates them from private ones by prioritizing informational offerings, national fiction, and documentary info-shows, and c) strategic differences of genres by ownership in each country.
\end{abstract}

\section{Funding}

This article is a result of the research project From hegemony to competition: transformations in the program strategies of European public televisions in the last 30 years (UE5) (PGC2018-094863-B-100, MCIU-Feder). 


\section{Keywords}

Programming; Scheduling; Genres; Public television; Private television; Europe; Television fiction; Television information; Prime-time.

\section{Programming on European general television channels}

The study of the schedules of generalist television is essential in understanding the role of public television in the audio-visual system. The changes in the audio-visual industry caused by the digitization and convergence of media and devices, and the changes in access to and consumption of content (Bustamante, 2010; Creeber; Hills, 2007; Dhoest; Simons, 2016; Meikle; Young, 2008; Prado; Fernández-Quijada, 2006) contextualize the editorial policies of the operators. This scenario is key to understanding possible programming strategies, as in other historical periods, such as privatization and deregulation (De-Moragas; Prado, 2000; Prado et al., 1999; De-Moragas; Garitaonandía; López, 1999) which broke with the previous beliefs (Montero, 2018).

The content currently offered reassesses certain genres that have been considered throughout the history of television as fundamental pillars. Fiction, together with information and infotainment or info-show are the main genres scheduled, both from a quantitative and qualitative perspective (De-Bens; De-Smaele, 2001; García-Muñoz; Larrègola, 2010). The latter also highlights the importance of the circulation of formats and their adaptation for local television markets in Europe (Bourdon, 2012; Cebrián-Herreros, 2004; Esser; Jensen, 2015; Chalaby, 2009; Frau-Meigs, 2006; Moran; Malbon, 2006; Wolf, 1984).

Theoretical contributions on genres (Creeber, 2001; Mittell, 2001; 2004; Wolf, 1984) have not only confirmed the survival and multiplication of specific genres, such as series or talk shows, but also favours the consolidation of others. The proliferation of formats, such as the docuseries or reality games, confirms the influence and hybridizations between genres (Beck; Hellmueller; Aeschbacher, 2012; Biressi; Nunn, 2005; Brants, 1998; Nabi, 2007; Kilborn, 1994; Rodríguez-Pastoriza, 1997). Furthermore, industry contextual factors are also essential in interpreting programmatic genres (Edgerton; Rose, 2008; Newcomb, 2005).

One of the aspects between public and commercially owned broadcasters, and which has been addressed by academic research, is the scheduling policy of fiction with respect to its origin (De-Bens; De-Smaele, 2001; Delgado; Prado; Navarro, 2017; Navarro; Prado, 2019; Prado; Delgado, 2010). Traditionally, imported content has been the majority programming of generalist channels (Buonanno, 2002; 2008; Bechelloni; Buonanno, 1997; Lacalle et al., 2018) and is a trend that the data from the European Audiovisual Observatory continues to confirm, excluding cultural and educational channels, and public channels (Lange, 2015; Kevin; Ene, 2015). In this sense, Delgado, Prado and Navarro (2017) already highlighted the distinctive features of the European general public channels (EU5) with a greater quantity of domestic content and a greater variety in the origin of acquired production.

In addition to the supply and distribution of genres, the scheduling policy regarding the time slots of content in the different European markets is essential. For this reason, the strategy of general television is also determined by the time location of its genres and formats (Bustamante; Zallo, 1988; Degn; Krogager, 2017; Wittebols, 2004; Faus-Belau, 1995). The importance of programmatic flow in the study of television content is essential to carry out an accurate interpretation of the data (Williams, 2004; Altman, 1986). Thus, the structure and distribution of content in the most popular general television schedules in Europe determines the current and future public television model compared to those already observed (Brown; Picard, 2005; Bustamante; Álvarez-Monzoncillo, 1999; Cebrián-Herreros, 2004; Contreras; Palacio, 2001; Eastman; Ferguson, 2006; De-Moragas; Prado, 2000; Richeri, 1983).

\section{Objectives and methodology}

The programming of the main, free digital general-interest channels of the five major European markets in 2018/2019 was analysed. The general objective is the analysis of the logic of the broadcasts, comparing based on a variety of factors such as country, time slots, and especially the ownership of the channels as the central axis of the study.

To achieve this objective, the following research questions were asked:

RQ1. What are the differences and similarities in the supply structure of the channels according to their ownership?

RQ2. What are the competitive strategies between public and private channels in the most competitive slot?

RQ3. What is the importance of domestic fiction to the programmatic policies of European channels?

The results presented in this article are unpublished data and part of the research project From hegemony to competition: transformations in the program strategies of European public television in the last 30 years (UE5) (PGC2018094863-B-100, MCIU-Feder). The sample includes the schedules of the 25 European general-interest channels in the five largest television markets in Europe in the 2018/19 season: Germany, Spain, France, Italy and the United Kingdom. The sample was broadcast during the week of November the $19^{\text {th }}$ to the $25^{\text {th }}, 2018$, starting at 06:00/07:00 until 01:00, which totalled more than 3,200 hours of broadcasts. For the analysis, the content analysis technique was used, employing the Euromonitor ${ }^{1}$ categories and variables. 
The genre classification considers three levels:

- the nature of the program identified (macrogenre);

- the program classification according to its format (genre);

- the main theme of the program (microgenre).

For this article, only the data from the first two levels was utilised: macrogenres and genres (Table 1).

The programming was also analysed according to the broadcast time slot. These ranges vary depending on the socio-demographic habits of the sample countries. Regarding the analysis of the slots, only the data for the prime-time and night-time slots have been used and aggregated for this article (Table 2).

Table 1. Macrogenres and genres

\begin{tabular}{|c|c|}
\hline Macrogenre & Genre \\
\hline Information & $\begin{array}{l}\text { Container, Current Affairs, Debate, Documentary, Event, Face to Face, Interview, Magazine, Mini Magazine, News, News Maga- } \\
\text { zine, Report. }\end{array}$ \\
\hline Fiction & $\begin{array}{l}\text { Animation Film, Animation Serial, Animation Series, Animation Short Film, Animation Sitcom, Animation TV Movie, Cinema, } \\
\text { Micro-series, Miniseries, Serial, Series, Short Film, Sitcom, Theatre, TV Movie. }\end{array}$ \\
\hline Info-show & $\begin{array}{l}\text { Cathodic Court, Chat, Debate, Docucomedy, Docudrama, Docuserie, Docusoap, Humor News Content, Interview, Reality } \\
\text { Game, Reality Show, Talk Show. }\end{array}$ \\
\hline Show & Candid Camera, Circus, Container, Debate, Festival, Gala, Humor/Satire, Magic, Music, Play-acting, Sexy Show, Special, Varieties. \\
\hline Game-show & Game, Quiz. \\
\hline Children & $\begin{array}{l}\text { Animal Fiction, Animation, Animation Costumes, Animation Puppet, Container, Cartoon, Diverse, Education, Fiction, Informa- } \\
\text { tion, Info-show, Live-action/Animated, Game show, Magazine, Mini Magazine, Model Animation, Music Video News, Play-ac- } \\
\text { ting, Report, Show, Storytelling, Stage Magic, Sport, Videogames. }\end{array}$ \\
\hline Youth & $\begin{array}{l}\text { Animation, Collage, Container, Cartoon, Debate, Diverse, Education, Report, Religious Programs, Fiction, Information, In- } \\
\text { fo-show, Game Show, Magazine, News, Sport, Show, Music Videos. }\end{array}$ \\
\hline Sports & Container, Live Broadcast, Magazine, Mini Magazine, Recorded Broadcast, Report, Sports News, Summary. \\
\hline Education & Container, Language Course, Postgraduate, Schooling, Training, Undergraduate. \\
\hline Others & $\begin{array}{l}\text { Archive, Bullfight, Capsule, Cinema Promotion, Classical Concert, Consumer protection, Container, Divulgation, Festival, Folklo- } \\
\text { re, Gymnastics, Industrial Information, Infomercials, Kitchen, Natural Environment, Others, Program Promotion, Teleshopping. }\end{array}$ \\
\hline
\end{tabular}

\section{Results}

\subsection{The television content scheduled on the generalist channels}

The dominant macrogenres aired in the five European markets are information, fiction and info-show. The differential factor between public and commercial broadcasters is the proportion in which they broadcast these three types of content. Public channels offer a large proportion of information programs, to which nearly half of their schedule is allocated, $20 \%$ more than the commercial channels. The privately-owned channels put fiction in first place, giving it a third of the schedule, almost double that of the public ones. To finish with the dominant block of macrogenres, info-show occupies almost a quarter of the commercial schedules, $10 \%$ more than public ones. Game-shows is the fourth macrogenre broadcast by the generalist channels and has great significance in the structure of the schedules, with almost double the percentage on public channels compared to the commercials.
Table 2. Sample description

\begin{tabular}{|c|c|c|c|}
\hline Country & Public & Commercial & Slot \\
\hline \multirow{3}{*}{ Germany } & Das Erste & ProSieben & \multirow{3}{*}{$\begin{array}{l}\text { Prime-time (19:00-22:30) } \\
\text { Night (22:30-01:00) }\end{array}$} \\
\hline & $Z D F$ & Sat.1 & \\
\hline & & $R T L$ & \\
\hline \multirow{2}{*}{ United Kingdom } & BBC One & Channel 4 & \multirow{2}{*}{$\begin{array}{l}\text { Prime-time (20:00-22:30) } \\
\text { Night (22:30-01:00) }\end{array}$} \\
\hline & BBC Two & ITV1 & \\
\hline \multirow{2}{*}{ France } & France 2 & TF1 & \multirow{2}{*}{$\begin{array}{l}\text { Prime-time (20:00-22:30) } \\
\text { Night (22:30-01:00) }\end{array}$} \\
\hline & France 3 & M6 & \\
\hline \multirow{3}{*}{ Italy } & Rai Uno & Canale 5 & \multirow{3}{*}{$\begin{array}{l}\text { Prime-time (20:30-22:30) } \\
\text { Night }(22: 30-01: 00)\end{array}$} \\
\hline & Rai Due & Italia 1 & \\
\hline & Rai Tre & Rete 4 & \\
\hline \multirow{4}{*}{ Spain } & La 1 & Antena 3 & \multirow{4}{*}{$\begin{array}{l}\text { Prime-time (20:30-22:30) } \\
\text { Night (22:30-01:00) }\end{array}$} \\
\hline & La 2 & Cuatro & \\
\hline & & La sexta & \\
\hline & & Telecinco & \\
\hline
\end{tabular}




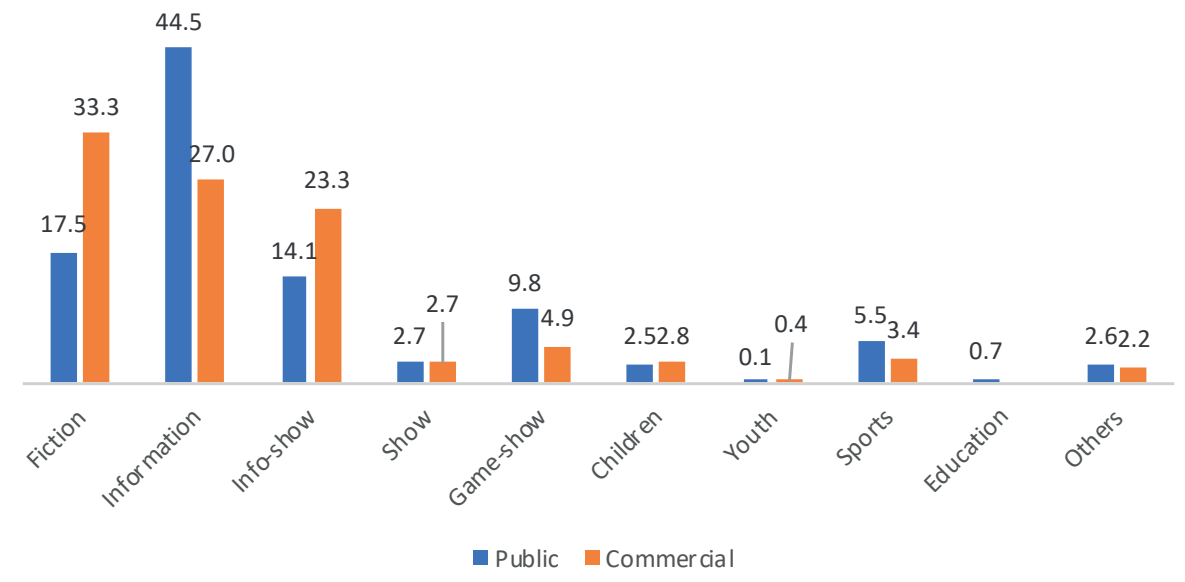

Graph 1. Structure of the offer by ownership (EU5), 2018-2019 (\%).

Source: PGC2018-094863-B-100 Project (MCIU-Feder).

The behaviour between public and commercial broadcasters in each of the five countries reveals a clear position regarding the three pillars of programming. Public channels opt for information as the leading content in the schedules of all the countries.

Table 3. Supply structure by country and ownership, 2018-2019 (\%).

\begin{tabular}{|l|c|c|c|c|c|c|c|c|c|c|}
\cline { 2 - 14 } & \multicolumn{2}{|c|}{ United Kingdom } & \multicolumn{2}{c|}{ Germany } & \multicolumn{2}{c|}{ France } & \multicolumn{3}{c|}{ Italy } & \multicolumn{2}{c|}{ Spain } \\
\cline { 2 - 14 } & Public & Comm & Public & Comm & Public & Comm & Public & Comm & Public & Comm \\
\hline Fiction & 9.0 & 21.3 & 26.7 & 44.6 & 16.4 & 38.8 & 14.3 & 42.8 & 21.9 & 20.9 \\
\hline Information & 41.3 & 21.8 & 40.9 & 21.9 & 38.0 & 15.8 & 47.7 & 24.7 & 54.0 & 41.1 \\
\hline Info-show & 22.1 & 30.3 & 6.5 & 25.1 & 11.2 & 18.8 & 18.6 & 18.5 & 10.3 & 24.4 \\
\hline Show & 1.3 & 0.4 & 1.1 & 3.0 & 1.3 & 1.1 & 6.5 & 4.0 & 1.8 & 3.4 \\
\hline Game-show & 15.7 & 12.4 & 6.8 & 1.8 & 15.9 & 2.8 & 7.3 & 2.4 & 4.4 & 6.5 \\
\hline Children & 0.9 & 2.6 & 5.0 & & 6.7 & 11.4 & 0.6 & 2.8 & & 0.8 \\
\hline Youth & & & 0.3 & & & 2.3 & 0.3 & 0.5 & & \\
\hline Sports & 5.5 & 7.0 & 10.7 & 3.5 & 7.7 & 2.0 & 3.6 & 3.3 & & 1.8 \\
\hline Education & & & & & & & & & 4.0 & \\
\hline Others & 4.2 & 4.2 & 2.0 & 0.1 & 2.8 & 7.0 & 1.1 & 1.0 & 3.6 & 1.1 \\
\hline
\end{tabular}

Source: PGC2018-094863-B-100 Project (MCIU-Feder).

Fiction is ranked in second place by the public channels in Germany, France and, although with a lower percentage, Spain. Italy and the United Kingdom instead select info-show as the second place macrogenre. Game-show, sports and children have a qualitative value and in some territories also a quantitative one. Public channels in the United Kingdom and France program around $16 \%$ of their schedules with game-shows.

Regardless of the general size of the macrogenre, in the results on the generic distribution of fiction the importance of serial fiction (series, serial, sitcom and animation series) is of primary importance for both public and commercial channels in Europe. This is clear to see with Series and Serial presence on all channels without exception. An interesting result emerges from the data on serial fiction on the public channels in France and Italy, with the proportion of this type of content reaching $85 \%$ of total fiction broadcast. Regarding commercial channels, the United Kingdom and Germany offer the highest proportion of serial fiction, with percentages above $75 \%$. Spanish public channels are the ones that broadcast the lowest levels of serial fiction.

Cinema continues to be a mandatory content for all countries and channels and, with the exception of Italian and French channels, it is the public-owned that broadcast the highest percentages. There is also a notable, national peculiarity in that there are some minority genres such as micro-series or short films that are only broadcast by French public channels. 
Table 4. Distribution by genre of fiction by ownership and country, 2018-2019 (\%)*.

\begin{tabular}{|c|c|c|c|c|c|c|c|c|c|c|c|c|}
\hline \multirow{5}{*}{ Public } & United Kingdom & 3.8 & 0.6 & 0.9 & 2.7 & 1.0 & & & & & & 9.0 \\
\hline & Germany & 4.8 & & & 4.9 & 14.1 & 2.9 & & & & & 26.7 \\
\hline & France & 1.0 & & & 2.9 & 10.5 & 0.7 & & 0.3 & 0.1 & 0.9 & 16.4 \\
\hline & Italy & 1.5 & 0.1 & & 5.6 & 7.1 & & & & & & 14.3 \\
\hline & Spain & 11.1 & & 0.6 & 6.4 & 1.5 & 2.3 & & & & & 21.9 \\
\hline \multirow{5}{*}{ Commercial } & United Kingdom & 4.9 & 8.0 & & 3.6 & 2.1 & & 2.7 & & & & 21.3 \\
\hline & Germany & 3.7 & 15.8 & & 8.8 & 10.6 & 0.5 & 3.4 & & & 1.8 & 44.6 \\
\hline & France & 2.2 & 2.3 & 1.5 & 9.8 & 7.9 & 15.1 & & & & & 38.8 \\
\hline & Italy & 11.3 & 4.9 & & 5.0 & 19.3 & & 1.5 & & & 0.9 & 42.9 \\
\hline & Spain & 7.8 & 1.1 & & 2.9 & 6,9 & 2.2 & & & & & 20.9 \\
\hline
\end{tabular}

Source: PGC2018-094863-B-100 Project (MCIU-Feder).

* Percentages on the total number of minutes of broadcast by channels with the same ownership.

Table 5. Distribution of genres of information by ownership and country, 2018-2019 (\%)*.

\begin{tabular}{|c|c|c|c|c|c|c|c|c|c|c|c|c|c|}
\hline \multirow{5}{*}{ Public } & United Kingdom & 19.6 & 8.3 & 0.6 & 1.9 & 8.7 & 2.2 & & & & & & 41.3 \\
\hline & Germany & 8.6 & 12.1 & 2.3 & 13.3 & 1.8 & 0.8 & 0.5 & 0.2 & & 1.0 & 0.3 & 40.9 \\
\hline & France & 16.7 & 12.2 & & 1.9 & 2.3 & & 3.6 & 1.2 & & 0.1 & & 38.0 \\
\hline & Italy & 23.4 & 12.5 & 0.6 & 1.1 & 0.4 & 1.9 & 2.4 & 1.1 & 3.3 & 0.7 & 0.4 & 47.8 \\
\hline & Spain & 11.3 & 12.5 & 0.2 & 3.7 & 18.8 & 1.1 & 1.1 & 0.4 & 4.9 & & & 54.0 \\
\hline \multirow{5}{*}{ Commercial } & United Kingdom & 10.8 & 6.2 & 0.4 & 1.6 & 1.5 & 1.3 & & & & & & 21.8 \\
\hline & Germany & 8.8 & 4.6 & 0.1 & 1.9 & 0.4 & 1.0 & & & 5.0 & & & 21.8 \\
\hline & France & 1.5 & 5.9 & 1,3 & 0.6 & 0.9 & 2.2 & 3.4 & & & & & 15.8 \\
\hline & Italy & 7.7 & 10.2 & & 2.0 & 0.3 & 0.3 & 0.8 & & 1.7 & 1.6 & & 24.6 \\
\hline & Spain & 20.9 & 10.4 & & & & 4.2 & 2.2 & 0.2 & 3.3 & & & 41,2 \\
\hline
\end{tabular}

Source: PGC2018-094863-B-100 Project (MCIU-Feder).

* Percentages on the total number of minutes of broadcast by channels of the same ownership.

The dominant information genres are Magazine and News, independently of other variables such as ownership or country and despite the differences in the size of information offering between the public and private channels. In all cases, without exception, general information Magazine programs are offered in the day-time and news programs as anchors for each time slot.

In-depth Information (documentary, report or interview) is more frequent on public channels, which also generally broadcast more genre diversity. In view of this, the documentary offerings on publicly owned channels in Spain and the United Kingdom stand out, being far greater than those of the remaining countries and ownership.
In-depth Information (documentary, report or interview) is given a higher priority on public channels, which also generally broadcast a greater diversity of genres 
Table 6. Genre distribution of info-show by ownership and country, 2018-2019 (\%) *

\begin{tabular}{|c|c|c|c|c|c|c|c|c|c|c|c|c|}
\hline & & 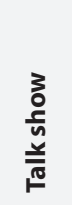 & 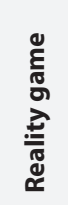 & 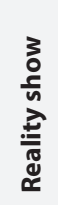 & 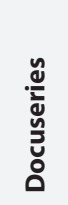 & 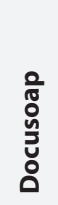 & 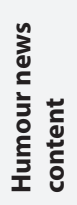 & 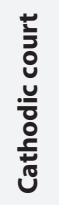 & $\begin{array}{l}\stackrel{0}{\pi} \\
\stackrel{0}{0} \\
\text { Dั }\end{array}$ & 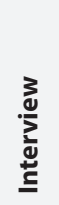 & 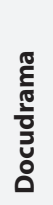 & 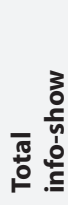 \\
\hline \multirow{5}{*}{ Public } & United Kingdom & 0.3 & 5.9 & 0.0 & 14.9 & & 0.4 & & 0.6 & & & 22.1 \\
\hline & Germany & 2.1 & & & 4.1 & & 0.3 & & & & & 6.5 \\
\hline & France & 5.2 & 0.8 & 1.7 & 3.0 & & & & & 0.5 & & 11.2 \\
\hline & Italy & 13.1 & 2.4 & 1.8 & & 0.5 & 0.3 & & & 0.5 & & 18.6 \\
\hline & Spain & 0.9 & 4.8 & & 3.9 & 0.7 & & & & & & 10.3 \\
\hline \multirow{5}{*}{ Commercial } & United Kingdom & 1.4 & 3.2 & & 3.7 & 0.5 & 1.0 & & & & & 9.8 \\
\hline & Germany & 0.6 & 9.4 & 1.2 & 11.6 & & & & & & 2.3 & 25.1 \\
\hline & France & & 13.4 & & 4.2 & 0.8 & 0.4 & & & & & 18.8 \\
\hline & Italy & 1.6 & 5.1 & 2.8 & 0.5 & & 3.0 & 5.5 & & & & 18.5 \\
\hline & Spain & 10.5 & 5.6 & 1.7 & 4.9 & & 0.8 & & & 0.9 & & 24.4 \\
\hline
\end{tabular}

Source: Project PGC2018-094863-B-100 (MCIU-Feder).

* Percentages on the total number of minutes of broadcast by channels of the same ownership.

In the case of the info-show, the main genres are docuseries, talk shows and reality games, the latter mostly broadcast by commercial channels. One phenomena of the info-show offering is the supply of documentary matrix formats, with special emphasis on self-contained plot programs. The docuseries is the most important info-show genre by British public channels and German commercial ones, while Italy stands out for its low level of support for this genre.

One of the differences between countries is the talk show - Spain mainly broadcasts them on commercial channels whereas in Italy they are mostly found on the public channels.

A genre that has practically disappeared from European schedules is the cathodic court, which is curiously popular on Italian commercial channels. Finally, humour news content is present in all countries and there are no differences in ownership.

The competitive contents par excellence in the peak-viewing slots during weekdays belong to the three leading macrogenres of European television. Here, again, the difference comes from the different strategies that public channels follow compared to the commercial ones. The exception to this is found in Germany, which emphasises fiction on both public and private channels.

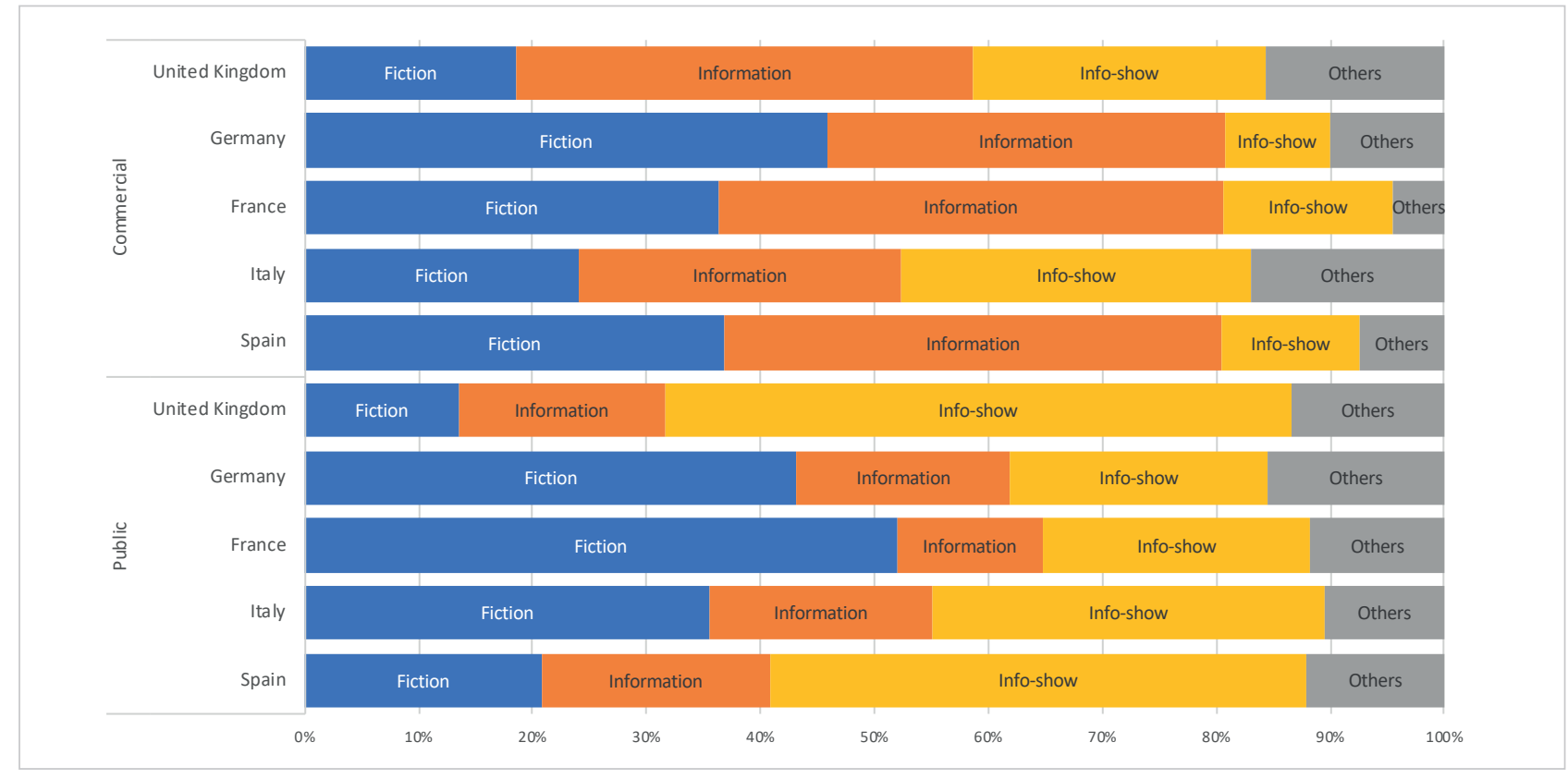

Graph 2. Structure of broadcast at prime-time and night by country and ownership, 2018-2019 (\%).

Source: PGC2018-094863-B-100 Project (MCIU-Feder) 
Public channels in the United Kingdom, France and Spain have all opted for information to be the most important macrogenre. Commercial channels in Spain and the UK focus on info-show while the French private channels prefer fiction. Italy is unusual in that the public channels broadcast similar amounts of information, fiction and info-show, whereas in the other countries there is a single, dominant macrogenre. However, Italian commercial channels follow the norm by airing mostly fiction. As for minority macrogenres, we can observe the presence of show and game-show, although the latter is above all a competitive content in access prime-time and is only found here in a residual form.

Table 7. Distribution of fiction genres, prime-time and night, 2018-2019 (\%)
The competitive contents par excellence in the peak-viewing slots during weekdays belong to the three leading macros of European television

\begin{tabular}{|c|c|c|c|c|c|c|c|c|c|c|c|}
\hline & & 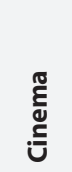 & $\frac{\varepsilon}{\stackrel{E}{S}}$ & 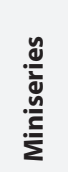 & 克 & 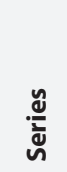 & $\begin{array}{l}\frac{0}{3} \\
\stackrel{0}{E} \\
\gtrless\end{array}$ & 号 & 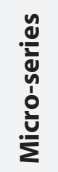 & 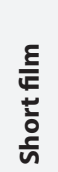 & 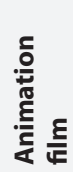 \\
\hline \multirow{2}{*}{ United Kingdom } & Public & 34.1 & 10.8 & 16.8 & 19.7 & 18.6 & & & & & \\
\hline & Commercial & 60.0 & & & 21.2 & 18.8 & & & & & \\
\hline \multirow{2}{*}{ Germany } & Public & 34.4 & & & 5.3 & 55.9 & 4.4 & & & & \\
\hline & Commercial & 20.3 & 13.2 & & 21.2 & 25.0 & 3.9 & 9.8 & & & 6.6 \\
\hline \multirow{2}{*}{ France } & Public & 9.5 & & & 22.1 & 57.0 & 7.4 & & 3.1 & 0.9 & \\
\hline & Commercial & 18.3 & 9.2 & 12.0 & 6.8 & 53.4 & 0.0 & & 0.3 & & \\
\hline \multirow{2}{*}{ Italy } & Public & 27.2 & & & 22.4 & 50.4 & & & & & \\
\hline & Commercial & 67.2 & & & 10.7 & 15.2 & & & & & 6.9 \\
\hline \multirow{2}{*}{ Spain } & Public & 78.5 & & 4.6 & 16.9 & & & & & & \\
\hline & Commercial & 65.7 & & & 11.0 & 6.5 & 16.8 & & & & \\
\hline
\end{tabular}

Source: PGC2018-094863-B-100 Project (MCIU-Feder).

In the distribution by genres in this timeslot, it can be clearly seen that cinema is highly important in all countries. This Fiction genre is very competitive, especially when considering the presence of at least one blockbuster per week. It is also a good tool in terms of offering alternative programming, in particular less commercial films such as art-house films, in foreign languages, of European origin, etc. By country, the behaviour is very uneven: in both the United Kingdom and Italy, cinema is broadcast mainly by the commercial channels, while the public channels broadcast mostly serial fiction. In Germany just the opposite happens, whereas all the French channels mainly concentrate on serial fiction. In Spain, the importance of cinema for both types of channels should be highlighted.

Table 8. Distribution of information genres, prime-time and night, 2018-2019 (\%).

\begin{tabular}{|c|c|c|c|c|c|c|c|c|c|c|c|c|}
\hline & & 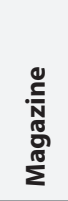 & $\frac{n}{2}$ & 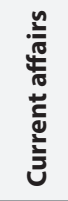 & 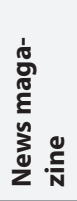 & 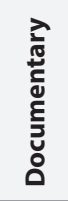 & $\begin{array}{l}\text { 늠 } \\
\frac{0}{d} \\
\simeq\end{array}$ & 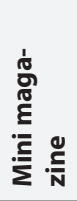 & 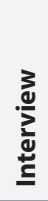 & 於 & \begin{tabular}{l}
0 \\
\multirow{0}{*}{} \\
$\stackrel{0}{0}$ \\
0
\end{tabular} & $\begin{array}{l}\text { 艺 } \\
\text { 岂 }\end{array}$ \\
\hline \multirow{2}{*}{ United Kingdom } & Public & 21.8 & 25.2 & 5.7 & & 29.0 & 18.3 & & & & & \\
\hline & Commercial & 12.2 & 28.5 & 4.7 & 8.0 & 31.1 & 15.5 & & & & & \\
\hline \multirow{2}{*}{ Germany } & Public & 5.8 & 34.9 & 21.1 & 5.4 & 8.3 & 7.7 & 4.9 & 1.8 & & 7.3 & 2.8 \\
\hline & Commercial & 42.9 & 25.7 & 2.7 & 13.4 & 6.5 & 8.8 & & & & & \\
\hline \multirow{2}{*}{ France } & Public & 36.5 & 23.1 & & & 18.0 & & 17.6 & 3.7 & & 1.1 & \\
\hline & Commercial & 26.9 & 37.1 & & & 8.4 & 13.2 & 14.4 & & & & \\
\hline \multirow{2}{*}{ Italy } & Public & 9.4 & 17.9 & 7.7 & 2.4 & & 15.9 & 0.7 & 8.2 & 28.1 & 9.7 & \\
\hline & Commercial & 7.4 & 6.4 & & & & 6.1 & & & 40.8 & 39.3 & \\
\hline \multirow{2}{*}{ Spain } & Public & 25.6 & 30.6 & 2.0 & 5.3 & 27.5 & 5.9 & & 3.1 & & & \\
\hline & Commercial & 9.9 & 49.9 & & & & 26.3 & 10.4 & 3.5 & & & \\
\hline
\end{tabular}

Source: Project PGC2018-094863-B-100 (MCIU-Feder). 
Regarding the information macrogenre broadcast during the prime-time and night time slots, the importance of the evening news, which is the anchor of the highest-rated slot, is highlighted. The exception to this is the Italian channels that broadcast their news earlier and where the relevance of the more dialogue based genres, such as debate, stand out on the commercial channels.

Current affairs is a genre typical of public channels, except in the United Kingdom, where it is a traditional genre for both types of ownership. Documentary is important and is used as a competitive element in some markets such as the UK and, at lower levels, in France and Germany.

Table 9. Distribution of info-show genres, prime-time and night, 2018-2019 (\%).

\begin{tabular}{|c|c|c|c|c|c|c|c|c|c|}
\hline & & 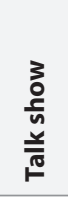 & 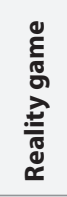 & 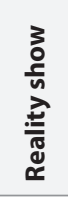 & 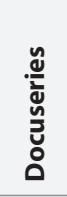 & 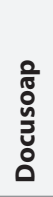 & 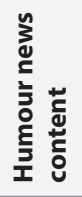 & 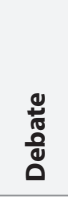 & 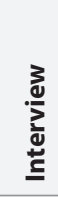 \\
\hline \multirow{2}{*}{ United Kingdom } & Public & 4.8 & 42.2 & & 35.8 & & 7.0 & 10.2 & \\
\hline & Commercial & 5.6 & 32.6 & 19.2 & 33.6 & 5.8 & 3.2 & & \\
\hline \multirow{2}{*}{ Germany } & Public & 88.5 & & & & & 11.5 & & \\
\hline & Commercial & 6.9 & 85.5 & & 7.6 & & & & \\
\hline \multirow{2}{*}{ France } & Public & 54.0 & 28.8 & & & & & & 17.2 \\
\hline & Commercial & & 82.5 & & 11.8 & & 5.7 & & \\
\hline \multirow{2}{*}{ Italy } & Public & 32.9 & 35.4 & 18.6 & & 3.5 & 4.8 & & 4.8 \\
\hline & Commercial & 18.9 & 33.0 & 11.8 & & & 36.3 & & \\
\hline \multirow{2}{*}{ Spain } & Public & 32.0 & 68.0 & & & & & & \\
\hline & Commercial & 15.8 & 45.1 & 7.2 & 17.5 & & 8.2 & & 6.2 \\
\hline
\end{tabular}

Source: PGC2018-094863-B-100 Project (MCIU-Feder).

It is in the prime-time and night where Reality-game becomes highly competitive, especially on commercial channels. However, in the United Kingdom, Italy and, above all, in Spain, the public channels also have the highest reality game figures in this slot.

While in Italy there are fewer differences in quantitative terms between the content aired in this period, it can be clearly seen that the strategy of public channels in Germany and France is based primarily on talk show, while commercial channels offer mainly reality game. In Spain, the high levels of reality game in $L a 1$ are due to the broadcast of the hit formats Operación Triunfo and Master chef Celebrity during the peak-viewing slot.

In the results on the origin of Fiction we differentiate:

- Fiction that has been produced in the country of origin (local);

- Fiction that has been purchased from other countries (imported);

- Fiction which is a co-production between the broadcasting country and other countries (co-produced).

In this case, the data on the origin of the fiction broadcast by the sample channels are incontrovertible: local production is more important to public channels in all countries without exception. Even in Italy and Spain, whose public channels broadcast more imported fiction than local production, it is these broadcasters that lead in domestic fiction when compared to the commercial ones.

In general terms, fiction broadcast by the European commercial channels is mostly purchased, with values reaching almost $85 \%$ in the case of Italy, being the country in the sample
It is in the prime-time and night slot where reality-game becomes highly competitive, especially on commercial channels

\begin{tabular}{|c|c|c|c|c|}
\hline & & Local & Imported & Co-produced \\
\hline \multirow{2}{*}{ United Kingdom } & Public & 55.4 & 35.6 & 9.0 \\
\hline & Commercial & 18.0 & 76.8 & 5.2 \\
\hline \multirow{2}{*}{ Germany } & Public & 78.1 & 19.3 & 2.6 \\
\hline & Commercial & 30.7 & 68.4 & 0.9 \\
\hline \multirow{2}{*}{ France } & Public & 58.6 & 41.4 & \\
\hline & Commercial & 21.5 & 75.9 & 2.6 \\
\hline \multirow{2}{*}{ Italy } & Public & 33.7 & 59.4 & 6.9 \\
\hline & Commercial & 10.3 & 84.5 & 5.2 \\
\hline \multirow{2}{*}{ Spain } & Public & 40.9 & 59.1 & \\
\hline & Commercial & 19.8 & 77.2 & 3.0 \\
\hline
\end{tabular}

Source: PGC2018-094863-B-100 Project (MCIU-Feder). 
that airs the highest percentage of imported fiction index. In all countries, the co-production of fiction is in the minority with respect to the other types of production. In the United Kingdom, Germany and Italy, it is the public channels that co-produce the most, while in France and Spain, this is reversed with the private channels broadcasting the most.
Local production is more important for public channels in all countries without exception

Table 11. Origin of imported fiction by country and ownership, 2018-2019 (\%).

\begin{tabular}{|c|c|c|c|c|c|c|c|}
\hline & & Europe & USA & USA + Europe & USA + other & $\begin{array}{c}\text { Europe + } \\
\text { other }\end{array}$ & Other \\
\hline \multirow{2}{*}{ United Kingdom } & Public & & 79.9 & 20.1 & & & \\
\hline & Commercial & 1.8 & 91.9 & 6.3 & & & \\
\hline \multirow{2}{*}{ Germany } & Public & 86.8 & 13.2 & & & & \\
\hline & Commercial & & 98.7 & 1.3 & & & \\
\hline \multirow{2}{*}{ France } & Public & 77.1 & 22.9 & & & & \\
\hline & Commercial & 6.4 & 84.0 & & 3.1 & & 6.5 \\
\hline \multirow{2}{*}{ Italy } & Public & 21.1 & 65.2 & 0.6 & 3.3 & 9.8 & \\
\hline & Commercial & 19.4 & 74.7 & 5.9 & & & \\
\hline \multirow{2}{*}{ Spain } & Public & 43.1 & 47.2 & & & & 9.7 \\
\hline & Commercial & 23.8 & 68.8 & 4.3 & & & 3.1 \\
\hline
\end{tabular}

Source: Project PGC2018-094863-B-100 (MCIU-Feder).

One of the most interesting results is determined from the data on the origin of purchased fiction. Once again, the differences between public and commercial channels are conclusive. The commercial broadcasters in the sample air mainly, and with very high percentages, fiction products acquired from the United States.

On Spanish, French and British public channels, the proportion of fiction broadcast from the United States is still higher than that from other territories, although in all cases the percentages are lower than those of the commercials. Clearly, the German and French public channels are the ones that invest more in broadcasting fiction of European origin, with very significant percentages. It is worth adding the peculiarity of British public channels, which broadcast notable levels of imported co-productions between European countries and the United States. Finally, it should be highlighted that the country with the largest difference between public and commercial channels regarding the origin of imported fiction is Germany. German public channels choose to purchase fiction mostly of European origin, while commercials buy almost $100 \%$ of their fiction from the United States.

\section{Conclusions}

The generalist model of free-to-air television, although still hegemonic, operates at extremely high levels of concurrence, competing not only in forms of distribution and consumption, but also against programs designed, produced and distributed internationally, with unattainable marketing strategies for national channels. This industrial context has been redefining the scheduling and productive strategies of generalist channels in general, and of the public television model in particular, which has to rethink and redefine its role in the system.

Our results point to a European public television (EU5) that competes with commercial television with a very similar strategy, but with clear, distinctive features.

Despite the fact that both types of ownership are opting for a schedule concentrated on three main macrogenres (fiction, information and info-show), the majority content of public channels is information (44.5\%), while the private channels broadcast more fiction (33.3\%). Another important point is info-show (23.3\%) which is much greater on commercial channels.

In addition to size, some differences are derived from the analysis of the genres of the programs broadcast by public channels. Thus, in the case of information, it is the public channels that offer more in-depth information, such as reports or documentaries. In the case of info-show, talk show and documentary type genres, such as the docuseries or the docusoap, are on all channels, but reality programmes (Reality-game, Reality-show) at a greater level on private channels, except in the United Kingdom. However, in the most competitive time slots, this genre becomes a strategic weapon for both the commercial and public channels, with significantly higher levels on Spanish public channels.

The majority content of public channels

is information, while private channels broadcast more fiction 
Finally, the serial fiction and cinema genres are found in similar proportions on all channels, regardless of their ownership. However, within serial fiction, sitcom is broadcast at higher percentages on private channels. There is also a difference, but only very little, that affects the broadcasting of minority fiction genres such as short films or micro-series, which are only found on public channels.

In the most competitive slots (prime-time and night) differences between the strategies of public and commercial channels were found. European private channels mostly focus on fiction and info-show, while public broadcasters mostly offer information. It is worth mentioning the case of the German public channels, which air mostly fiction, and that of the Italian public channels that schedule very similar percentages of the three pillar macrogenres at prime-time and the night slots.

Finally, one of the elements that most characterizes the strategy of public and private channels in Europe is their fiction production policy. Local productions by public channels exceed those of private channels in all countries without exception. Furthermore, in the case of the British, German and French public channels, the broadcast of domestically produced fiction is much higher than that of imported fiction. These results reinforce the dynamic role of European public television for the local fiction production industry, although to differing levels depending on the country.

In addition, the origin of imported fiction also marks a clear divergence between channels of different ownership. Commercial channels purchase mostly from the United States and at higher percentages than public corporations. Acquisition of intra-European fiction titles is low with the noteworthy exception of public channels in Germany and smaller quantities by French public channels.

In short, without going into qualitative elements that would give even more differentiation arguments, the quantitative results on the programmatic offerings of the countries in the sample offer a scenario in which, while still competing, European public channels construct their schedules by paying more attention to Information, especially in-depth Information, local Fiction production and the intra-European acquisition of fiction, and additionally, to certain formats of Info-show but to a lesser extent than commercial channels. Despite the narrative created in certain contexts on the homogeneity of programming policies between public and commercials, the findings of this study reveal substantial differences depending on the ownership of the channel.

\section{Notes}

1. Euromonitor is a permanent television observatory in Europe created by a group of European researchers (Paolo Baldi, Ian Connell, Claus Dieter Rath and Emili Prado) with the support of the RAI VQPT service, operating since 1989. Up to 1995, the head office was based in Geneva until relocating to the Universitat Autònoma de Barcelona where it operates under the direction of Emili Prado, Research Group on Image, Sound and Synthesis (GRISS-UAB), Ref. 2017 SGR1674.

\section{References}

Altman, Rick (1986). "Television/sound”. In: Modleski, Tania. Studies in entertainment: Critical approaches to mass culture. Bloomington: Indiana University Press, pp. 39-53. ISBN: 0253355664

Bechelloni, Giovanni; Buonanno, Milly (1997). Television, fiction and identities: America, Europe, nations. Napoli: Ipermedium Libri. ISBN: 8886908113

Beck, Daniel; Hellmueller, Lea C.; Aeschbacher, Nina (2012). "Factual entertainment and reality TV". Communication research trends, v. 31, n. 2, pp. 4-27.

http://cscc.scu.edu/trends/v31/CRT_v31_n2_June_2012.pdf

Biressi, Anita; Nunn, Heather (2005). Reality TV: Realism and revelation. London: Wallflower Press. ISBN: 9781 904764045

Bourdon, Jérome (2012). "From discrete adaptation to hard copies: The rise of formats in European television". In: Oren, Tasha; Shahaf, Sharon. Global television formats: Understanding television across borders. New York, Oxon: Routledge, pp. 111-127. ISBN: 9780415965446

Brants, Kees (1998). “Who's afraid of infotainment?". European journal of communication, v. 13, n. 3, pp. 315-335. https://doi.org/10.1177/0267323198013003002

Brown, Allan; Picard, Robert G. (2005). Digital terrestrial television in Europe. New Jersey: Lawrence Erlbaum Associates. ISBN: 9780805853872

Buonanno, Milly (2002). Eurofiction. Television fiction in Europe. Report 2001. Strasbourg: Hypercampo. ISBN: 9287150281

Buonanno, Milly (2008). The age of television: Experiences and theories. Bristol: Intellect. ISBN: 9781841501819 
Bustamante, Enrique (2010). "Digital television scenarios. Quality contents in the new audiovisual structure". Infoamérica: Iberoamerican communication review, n. 3-4, pp, 137-154.

https://www.infoamerica.org/icr/n03_04/bustamante.pdf

Bustamante, Enrique; Álvarez-Monzoncillo, José-María (1999). Presente y futuro de la televisión digital. Madrid: Edipo. ISBN: $848836508 \mathrm{X}$

Bustamante, Enrique; Zallo, Ramón (1988). Las industrias culturales en España (grupos multimedia y transnacionales): prensa, radio, TV, libro, cine, disco, publicidad. Madrid: Akal. ISBN: 8476003390

https://www.infoamerica.org/icr/n03_04/bustamante.pdf

Cebrián-Herreros, Mariano (2004). Modelos de televisión: generalista, temática y convergente con internet. Barcelona: Paidós. ISBN: 8449315379

Chalaby, Jean K. (2009). Transnational television in Europe: Reconfiguring global communications networks. New York: I. B. Tauris. ISBN: 9781845119539

Contreras, José-Miguel; Palacio, Manuel (2001). La programación de televisión. Madrid: Síntesis. ISBN: 847738858X

Creeber, Glen (2001). Television genre book. London: British Film Institute. ISBN: 0851708498

Creeber, Glen; Hills, Matt (2007). "TvIII: Into, or towards, a new television age?". New review of film and television studies, v. 5, n. 1, pp. 1-4.

https://doi.org/10.1080/17400300601140118

De-Bens, Els; De-Smaele, Hedwig (2001). "The inflow of American television fiction on European channels revisited". European journal of communication, v. 16, n. 6, pp. 51-76.

https://doi.org/10.1177/0267323101016001003

Degn, Hans-Peter; Krogager, Stinne-Gunder-Strøm (2017). “Danish televisión drama series: A Sunday evening phenomenon". Critical studies in television, v. 12, n. 1, pp. 362-379.

https://doi.org/10.1177/1749602017730261

Delgado, Matilde; Prado, Emili; Navarro, Celina (2017). “Ficción televisiva en Europa (EU5): origen, circulación y puesta en parrilla". El profesional de la información, v. 26, n. 1, pp. 132-140.

https://doi.org/10.3145/epi.2017.ene.14

De-Moragas, Miquel; Garitaonandía, Carmelo; López, Bernat (1999). Televisión de proximidad en Europa: experiencias de descentralización en la era digital. Bellaterra: Universitat Autònoma de Barcelona.

De-Moragas, Miquel; Prado, Emili (2000). La televisió pública a l'era digital. Barcelona: Pòrtic. ISBN: 9788473066174

Dhoest, Alexander; Simons, Nele (2016). "Still 'watching' TV? The consumption of TV fiction by engaged audiences". Media and communication, v. 4, n. 3, pp. 176-184.

https://doi.org/10.17645/mac.v4i3.427

Eastman, Susan; Ferguson, Douglas (2006). Media programming: strategies and practices. Belmont, California: Thomson/Wadsword. ISBN: 9781111344474

Edgerton, Gary; Rose, Brian-Geoffrey (2008). Thinking outside the box. A contemporary television genre reader. Kentucky: University Press. ISBN: 9780813191942

Esser, Andrea; Jensen, Pia-Majbritt (2015). "The use of international television formats by public service broadcasters in Australia, Denmark and Germany". International communication gazette, v. 77, n. 4, pp. 359-383.

https://doi.org/10.1177/1748048514568766

Faus-Belau, Ángel (1995). La era audiovisual. Historia de los primeros cien años de la radio y la televisión. Barcelona: Ediciones Internacionales Universitarias. ISBN: 8487155367

Frau-Meigs, Divina (2006). "Big brother and reality TV in Europe. Towards a theory of situated acculturation by the media". European journal of communication, v. 21, n. 1, pp. 33-56.

https://doi.org/10.1177/0267323106060988

García-Muñoz, Núria; Larrègola, Gemma (2010). “La TDT en Europa: modelos de programación”. Telos, Cuadernos de comunicación e innovación, v. 84, pp. 65-72.

https://telos.fundaciontelefonica.com/archivo/numero084/modelos-de-programacion

Kevin, Deirdre; Ene, Laura (2015). European fiction works on TV channels. Strasbourg: European Audiovisual Observatory.

https://rm.coe.int/16807835c7 
Kilborn, Richard (1994). "How real can you get?: Recent developments in 'reality' television". European journal of communication, v. 9, n. 4, pp. 421-439.

https://doi.org/10.1177/0267323194009004003

Lacalle, Charo; Gómez, Beatriz; Sánchez, Mariluz; Pujol, Cristina; Ferrer, Rosa (2018). “España: innovación e hibridación de géneros y formatos". En: Vasallo-de-Lopes, Maria-Immacolata; Orozco, Guillermo. Obitel 2018. Ficción televisiva iberoamericana en plataformas de video on demand. Porto Alegre: Globo-Sulina, pp. 197-228. ISBN: 9788520507940 https://bit.ly/2lyOOa9

Lange, André (2015). Fiction on European TV channels (2006-2013). Strasbourg: European Audiovisual Observatory. ISBN: 9789287180797

Meikle, Graham; Young, Sherman (2008). "Beyond broadcasting? TV for the twenty-first century". Media international Australia, v. 126, n. 1, pp. 67-70.

https://doi.org/10.1177/1329878x0812600108

Mittell, Jason (2001). "A cultural approach to television genre theory". Cinema journal, v. 40, n. 3, pp. 3-24. https://doi.org/10.1353/cj.2001.0009

Mittell, Jason (2004). Genre and television. From cop shows to cartoons in American culture. New York: Routledge. ISBN: 9780415969031

Montero, Julio (2018). Una televisión con dos cadenas. La programación en España (1956-1990). Madrid: Cátedra. ISBN: 9788437638409

Moran, Albert; Malbon, Justin (2006). Understanding the global TV format. Bristol, Portland: Intellect. ISBN: 1841501328

Nabi, Robin L. (2007). "Determining dimensions of reality: A concept mapping of reality TV landscape". Journal of broadcasting \& electronic media, v. 51, n. 2, pp. 371-390.

https://doi.org/10.1080/08838150701307111

Navarro, Celina; Prado, Emili (2019). "Television buyers in the digital era: A comparative study of the UK and Spain". International communication gazette, v. 81, n. 6-8, pp. 727-747.

https://doi.org/10.1177/1748048518822612

Newcomb, Horace (2005). "Studying television: Same questions, different contexts". Cinema journal, v. 45, n. 1, pp. 107-111.

https://doi.org/10.1353/cj.2006.0010

Prado, Emili; Delgado, Matilde (2010). "La television generalista en la era digital. Tendencias internacionales de programación". Telos, Cuadernos de comunicación e innovación, v. 84, pp. 52-64.

Prado, Emili; Delgado, Matilde; García-Muñoz, Nuria; Huertas, Amparo; Larrègola, Gemma; Perona, Juan-José (1999). "El fenónemo infoshow: la realidad está ahí fuera". Área 5, Revista de comunicación audivisual y publicitaria, v. 6, pp. $197-210$

Prado, Emili; Fernández-Quijada, David (2006). "The role of public service broadcasters in the era of convergence - A case study of Televisió de Catalunya". Communication \& strategies, v. 62, pp. 49-69.

Richeri, Giuseppe (1983). La televisión: entre servicio público y negocio. Estudios sobre la transformación televisiva en Europa Occidental. Barcelona: Gustavo Gili. ISBN: 9686085726

Rodríguez-Pastoriza, Francisco (1997). Perversiones televisivas: una aproximación a los nuevos géneros audiovisuales. Madrid: Instituto Oficial de Radio Televisión Española. ISBN: 8488788274

Williams, Raymond (2004). Television: Technology and cultural form. London: Routledge. ISBN: 0415314569

Wittebols, James (2004). The soap opera paradigm: television programming and corporate priorities. New York: Rowman and Littlefield. ISBN: 0742520021

Wolf, Mauro (1984). "Géneros y televisión”. Anàlisi: Quaderns de comunicació i cultura, n. 9, pp. 189-198.

El profesional de la

información

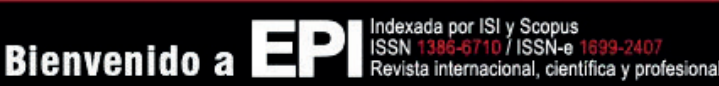

http://www.elprofesionaldelainformacion.com

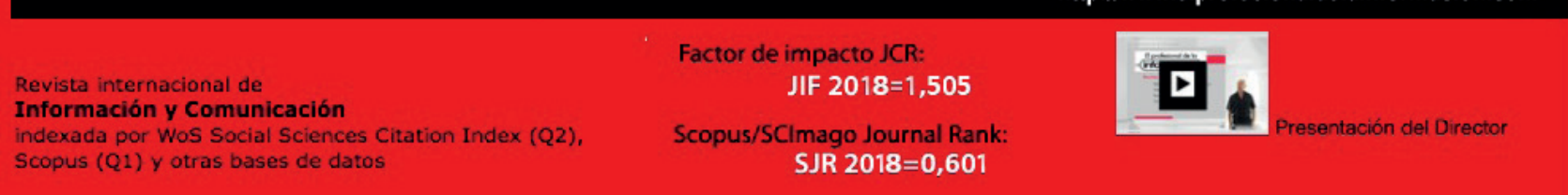

